\title{
Stilts do not protect against crawlers: Limpkins preyed on by Tegu Lizards at an urban park
}

\author{
Juliana Vaz Hipolito' ${ }^{1}$ Ivan Sazima ${ }^{2,3}$ \\ Instituto de Biologia, Universidade Estadual de Campinas, Campinas, São Paulo, Brazil. \\ Museu de Zoologia, Universidade Estadual de Campinas, Campinas, São Paulo, Brazil. \\ 3 Corresponding author: isazima@gmail.com
}

Received on 25 September 2018. Accepted on 26 November 2018.

\begin{abstract}
Limpkin (Aramus guarauna) is a long-legged wading bird that forages mostly in wetlands in the open and occasionally under tree cover. This large bird is cautious and frequently scans its immediate environs when active or resting. Records of adult Limpkin predators are scarce and restricted to two very large aquatic reptiles, the American Alligator (Alligator mississippiensis) in North America and the Yellow Anaconda (Eunectes notaeus) in South America. Herein we report on two Limpkins killed and eaten by Black and White Tegus (Salvator merianae) at an urban park in southeastern Brazil. One of the Limpkins was still alive when we came across the predation event, whereas the other Limpkin seemed freshly killed. The first Limpkin was already sprawled on the ground and occasionally opened the bill, vocalised hoarsely and flapped the wings, while the Tegu repeatedly bit the bird on several body parts, which gradually weakened the bird. The Limpkin died when the Tegu bit hard the bird on the head and crushed the skull. In the second event the bird was bitten on several body parts and, thus, we assume that it was also killed by the Tegu that was eating the fresh corpse. The two events comprised two Tegu individuals recognisable by natural marks. Limpkins killed and consumed by Tegus probably are a rare occurrence. Tegus are large by Neotropical lizard standards, but are small compared with the other two very large reptiles known to prey on Limpkins. Presently, only three reptilian species are documented as predators of adult Limpkins.
\end{abstract}

KEY-WORDS: Aramidae, predation, Teiidae, urban area, wading bird.

Limpkin (Aramus guarauna) is a long-legged wading bird that forages mostly in wetlands in the open and occasionally under tree cover (Bryan 1996, 2002). This large bird is cautious and frequently scans its immediate vicinity when active or resting, especially if sitting on the ground (I.S., pers. obs.). Records of adult Limpkin predators are scarce and restricted to two very large aquatic reptiles, the American Alligator (Alligator mississippiensis) in North America and the Yellow Anaconda (Eunectes notaeus) in South America (Strussmann 1997, Bryan 2002). Herein we report on two Limpkins attacked and eaten by Black and White Tegus (Salvator merianae) at an urban park in southeastern Brazil.

We recorded the two predation events of Limpkins by Tegus at the Parque Ecológico Professor Hermógenes de Freitas Leitão Filho $\left(22^{\circ} 48^{\prime} 42^{\prime \prime} \mathrm{S}\right.$; $\left.47^{\circ} 04^{\prime} 26^{\prime \prime} \mathrm{W}\right)$ in Campinas, São Paulo state, southeastern Brazil. The park has a total area of $0.13 \mathrm{~km}^{2}$, of which about $75 \%$ is occupied by a large pond surrounded by native and exotic vegetation composed of trees, bushes and grass patches. We observed the Limpkins and the Tegus with bare eye and recorded their interactions in video and photos with a digital camera at a distance of 2-3 m. Throughout the observational sessions, we used the "ad libitum" and "sequence" samplings (Altmann 1974), which are adequate to record fortuitous or rare events. Voucher digital photographs of the two predation events are on file at the Museu de Zoologia da Universidade Estadual de Campinas (ZUEC).

On 08 February 2018 at early afternoon we recorded a Tegu crawling under tree cover, while a Limpkin walked nearby well aware of the large lizard (Fig. 1A). Shortly after, we heard a thrashing noise and hoarse calls nearby. Then we came across the first predation event, the Limpkin still alive but sprawled on the ground. It occasionally opened the bill, vocalised hoarsely and flapped the wings (Fig. 1B), while the Tegu repeatedly bit the bird on several body parts. This biting gradually weakened the Limpkin, which died when the Tegu bit hard the bird on the head and crushed the skull drawing blood at the base of the bill (Fig. 1C). After the kill, the Tegu pulled off feathers from the bird's body (Fig. 1D) and began to tear flesh pieces to consume.

On 16 February 2018 we recorded the second predation event, also at early afternoon. When we became aware of this event, the Limpkin seemed freshly killed and was bitten on several body parts. Consequently, we assumed that it was killed by the Tegu that was tearing flesh from the corpse (Fig. 2A \& B). The two events we recorded comprised two Tegu individuals recognisable by natural marks. 


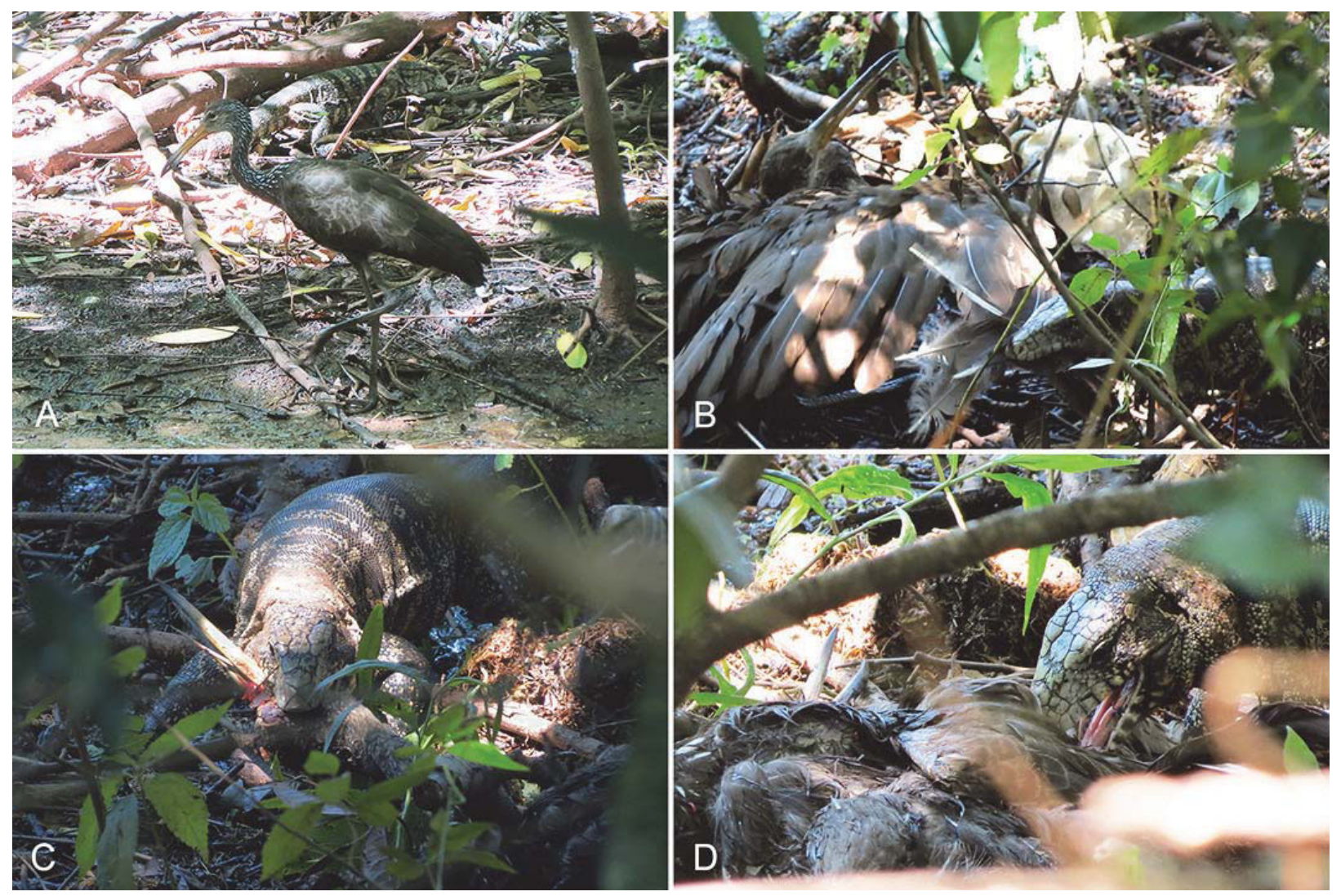

Figure 1. An adult Tegu Salvator merianae (foreground) moves close to an adult Limpkin Aramus guarauna (A). Note relative size of both animals and the Limpkin's long legs ("stilts"). A wounded Limpkin sprawled on the ground, its eyes and bill partly open (upper left) and a Tegu with feathers protruding from its mouth (lower right) (B). The Limpkin's head is bitten hard by the Tegu, crushing the skull and drawing blood on the base of bill $(\mathbf{C})$. Feathers from the bird's body and wings are pulled off by the Tegu (D). Photo author: J.V. Hipolito.

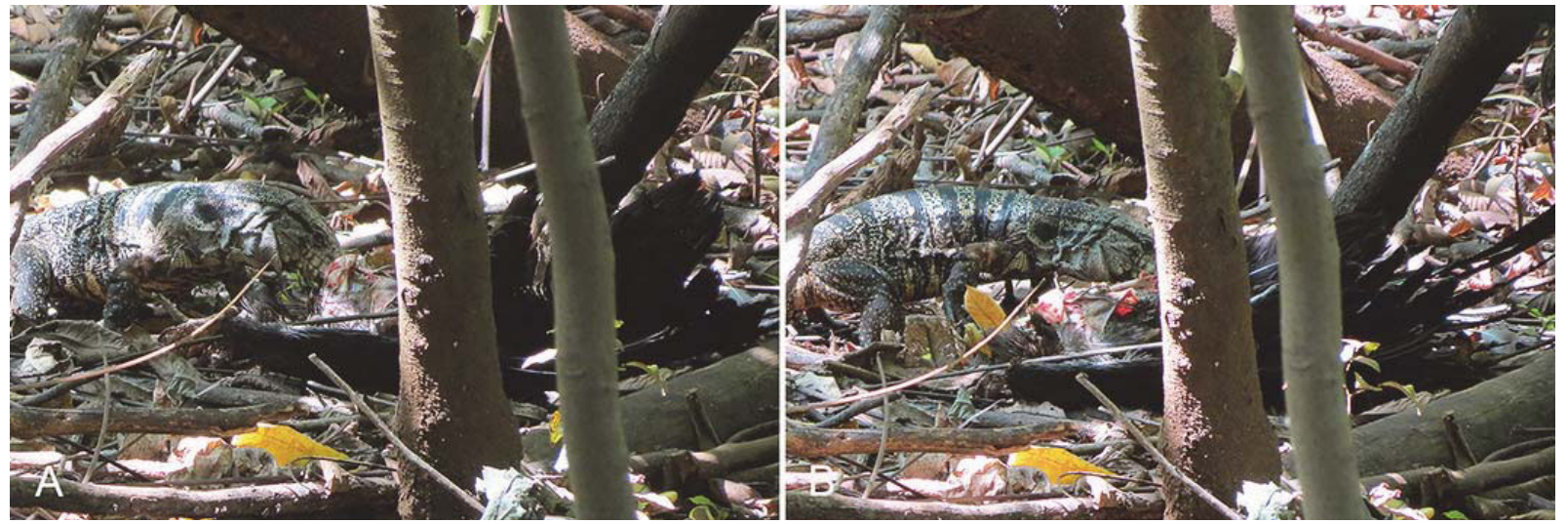

Figure 2. The fresh body of a second killed Limpkin provides food for another adult Tegu (A), eight days after the first Limpkin kill. The vivid red parts on the Limpkin corpse (centre) indicate a recent death (B). Photo author: J.V. Hipolito.

To the best of our knowledge, the predation events we recorded are the first instance of adult Limpkins killed and consumed by a medium-sized reptile. Limpkins are large and long-legged wading birds, with about $70 \mathrm{~cm}$ total length and about $60 \mathrm{~cm}$ tall (Bryan 1996, 2002, Sick 1997). The Black and White Tegu is large by Neotropical lizard standards, with about $120 \mathrm{~cm}$ total length (Pianka $\&$ Vitt 2003). Thus, predation on Limpkins by these lizards may be a rare event, the more so as birds this size remain unrecorded as prey for the Black and White Tegu, which is mostly an omnivorous scavenger at the study site and hunts considerably smaller prey (Sazima \& D'Angelo 2013). Moreover, both Tegus and Limpkins are a common sight at the study site (Corbo et al. 2013, Sazima \& D'Angelo 2013), but these birds killed and devoured by the lizards were never recorded before.

We were unable to tell whether the first predation event was favoured by a weakening condition such as disease or injury or the Limpkin sat and did not perceive the approaching Tegu in time to evade the attack. Limpkins sit rarely (Bryan 2002) but at our study site this behaviour is not rare, especially at open places where 
the bird has a good view of the immediate surroundings (I.S., pers. obs.). Apart from the possibility of the Tegu attacking an inattentive Limpkin sitting under a tree cover, there still remains the chance that the Limpkin was partly disabled. Whatever the case, two Limpkins killed and eaten by two Tegus at the same site in the interval of about a week is noteworthy.

At present, only three reptile species are documented as predators of adult Limpkins: American Alligator, Yellow Anaconda, and Black and White Tegu (Strussmann 1997, Bryan 2002, present paper). Alligators prey on mediumsized and large aquatic birds, including rails, cormorants, anhingas, ibises, and herons (Wolfe et al. 1987, Rice 2004, Saalfeld et al. 2011), and the same does the Yellow Anaconda, which may prey on birds as large as storks, ibises, and screamers (Strussmann 1997). These are very large reptilian predators when compared with the Tegu, which indicates the probable rarity of predation events on Limpkins by Tegus. Additional, natural history-oriented studies and observations may test this assumption.

\section{ACKNOWLEDGEMENTS}

We thank the staff of the Parque Ecologico Professor Hermógenes de Freitas Leitão Filho for allowing our field studies at the park. I.S. thanks Marlies Sazima for loving support.

\section{REFERENCES}

Altmann J. 1974. Observational study of behavior: sampling methods. Behaviour 49: 227-267.

Bryan D.C. 1996. Family Aramidae (Limpkin), p. 90-95. In: del Hoyo J., Elliot A. \& Sargatal J. (eds.). Handbook of the birds of the world, v. 3 (Hoatzin to auks). Barcelona: Lynx Editions.

Bryan D.C. 2002. Limpkin (Aramus guarauna). In: Poole A.F. \& Gill F.B. (eds.). The birds of North America. Ithaca: Cornell Lab of Ornithology. https://doi.org/10.2173/bna.627 (access on 12 June 2018).

Corbo M., Macarrão A., D'Angelo G.B., Almeida C.H., Silva W.R. \& Sazima I. 2013. Aves do campus da Unicamp e arredores. Vinhedo: Avisbrasilis.

Pianka E.R. \& Vitt L.J. 2003. Lizards: windows to the evolution of diversity. Berkeley: University of California Press.

Rice A.N. 2004. Diet and condition of American Alligators (Alligator mississippiensis) in three central Florida lakes. MSc. Dissertation. Gainesville: University of Florida. http://aquaticcommons. org/5059/1/Rice_A_2004.pdf (access on 20 November 2018).

Saalfeld D.T., Conway W.C. \& Calkins G.E. 2011. Food habits of American Alligators (Alligator mississippiensis) in east Texas. Southeastern Naturalist 10: 659-672.

Sazima I. \& D'Angelo G.B. 2013. Range of animal food types recorded for the Tegu Lizard (Salvator merianae) at an urban park in south-eastern Brazil. Herpetology Notes 6: 427-430.

Sick H. 1997. Ornitologia brasileira. Rio de Janeiro: Editora Nova Fronteira.

Strüssmann C. 1997. Hábitos alimentares da Sucurí-amarela Eunectes notaeus (Cope, 1862) no Pantanal Mato-Grossense. Biociências 5: $35-52$.

Wolfe J.L., Bradshaw D.K. \& Chabreck R.H. 1987. Alligator feeding habits: new data and a review. Northeast Gulf Science 9: 1-8.

Associate Editor: Cristiano S. Azevedo. 